\title{
DIETARY LYSINE AND METHIONINE REQUIREMENT OF BREAM ABRAMIS BRAMA ORIENTALIS JUVENILE
}

\author{
GHOMI, M. R.* \& ALIZADEHNAJD, A. \\ Department of Fisheries Sciences, Islamic Azad University-Tonekabon Branch, 46817, Tonekabon, \\ Iran \\ *Contact author: mghomi@tonekabon.iau.ac.ir
}

\begin{abstract}
Ghomi, M. R. \& Alizadehnajd, A. (2012) Dietary lysine and methionine requirement of bream Abramis brama orientalis juvenile. Braz. J. Aquat. Sci. Technol. 16(1):79-82. elSSN 1983-9057. This study was conducted to estimate the dietary lysine and methionine requirement of juvenile Abramis brama orientalis based on growth performance. Juveniles (initial body weight, $0.80 \pm 0.08 \mathrm{~g}$ ) fed 3 times daily with $5 \%$ body weight per day with the basal diet containing 0.3 and $0.6 \%$ lysine and methionine alone or in combination. The juveniles were cultured in indoor tanks with three replicates per dietary treatment. Bream juveniles fed the diet contained both lysine and methionine at $0.6 \%$ showed relatively higher specific growth rate and slightly lower feed conversion ratio at the end of the feeding trial. On the other hand, diet supplemented with both lysine and methionine has better improved the growth rate of the juveniles.
\end{abstract}

Keywords: Abramis brama orientalis, lysine, methionine, specific growth rate, feed conversion ratio.

INTRODUCTION

The expansion of global aquaculture is increasing the demand for aquaculture feed which is the prime input in fish culture practices (Singh et al., 2011). Diet must contain the necessary nutritional requirements for fish to ensure the best growth (Ghomi et al., 2012). To ensure maximal growth, fish species need ten indispensible amino acids in their diet. Among all indispensable amino acids, lysine is often the most limiting amino acid in the ingredients used to prepare fish diets (Mai et al., 2006). Lysine is not only involved in protein synthesis, but also along with methionine serve as the precursor of carnitine which carries fatty acids across mitochondrial membranes and facilitates their oxidation to produce energy (Deng et al., 2010).

Several studies have shown reduced growth and poor diet conversion as a result of dietary lysine deficiency in fish (Wang et al., 2005; Deng et al., 2010; Zhou et al., 2007). Methionine is an indispensable amino acid which takes part in protein synthesis and other important physiological functions. On the other hand, methionine and cystine are the main source of sulfur amino acids for animals. However, cystine is not essential as it can be synthesized from methionine (Zhou et al., 2006). Addition of methionine to the diet increased growth performance of several fish species including Juvenile Cobia Rachycentron canadum (Zhou et al., 2006), carp Cyprinus carpio (Schwarz et al., 1998) and gibel carp Carassius auratus gibelio (Hu et al., 2008).
Bream (Abramis brama orientalis Berg, 1962) is an important bony fish species of cyprinid family exists in the Caspian Sea basin including Russian, Azeri and Iranian waters. In Iran, it resides in the Anzali wetland and the neighboring Caspian coast (Kiabi et al., 1999). Overfishing and habitat deterioration have contributed to the drastic decline of bream population to almost zero in 1980s. Therefore artificial breeding of bream is ongoing in Iran since 1986 to overcome the decline of stocks (Ghasemi et al., 2007). Currently more than 16 million of juveniles are produced annually and released to rivers. This species accept culture conditions as well and reach up to $250 \mathrm{~g}$ within five month of polyculture with Chinese carps (Amini et al., 2007).

So far no information has been published regarding dietary lysine and methionine requirement of juvenile bream Abramis brama orientalis. Therefore this study was undertaken to estimate the dietary lysine and methionine requirement of this species based on growth performance.

\section{MATERIALS AND METHODS}

\section{Experimental condition, fish and feeding}

Juvenile bream (Abramis brama orientalis) with average weight of $0.8 \mathrm{~g}$ were obtained from Shahid Ansari Hatchery (Rasht, Guilen Province, Iran). These juveniles were produced in earthen ponds by semi artificial propagation of broodstocks which fed with commercial SFK (Chine Co., Tehran, Iran) diet 
containing $47 \%$ crude protein, $14 \%$ lipid, $10.5 \%$ ash, $3 \%$ crude fiber, and $11.8 \%$ moisture. Juvenile were transferred from earthen ponds to indoor tanks and acclimated to culture conditions for 3 days and then placed in $2000 \mathrm{~L}$ VNIRO tanks (29 tanks total). After this period, the growth trial was conducted for 35 days and juvenile were fed diet containing lysine $(0,0.3$, and $0.6 \%)$, methionine $(0,0.3$, and $0.6 \%)$ or their combination. Three tanks were randomly selected to each dietary treatment with 300 juvenile per tank. Feeding rate was adjusted at $5 \%$ according to fish body weight. Juvenile were hand fed three times a day with equal amounts at each feeding time. During the experimental period, aeration was continuously supplied and water temperature was monitored daily and was $21 \pm 1{ }^{\circ} \mathrm{C}$ during the experiment.

\section{Growth factors}

Sampling was carried out at the beginning of study and the end of the rearing. At each sampling time 30 specimens were removed to monitor fish growth. The specific growth rate (SGR) was measured by the weight to nearest $0.01 \mathrm{~g}$. The SGR calculated as follows: SGR $(\% \mathrm{~g} /$ day $)=100 \times\left(\operatorname{InW}_{\mathrm{t}}-\ln \mathrm{W}_{\mathrm{o}}\right) / \mathrm{t}$, where $\mathrm{W}_{\mathrm{t}}$ and $W_{0}$ are the weight of the juveniles at day $t$ (final day) and at the beginning of the experiment, respectively. Feed conversion ratio (FCR) was calculated as $\mathrm{FCR}=\mathrm{Fc} / \mathrm{DW}$, where $\mathrm{Fc}$ is the total dry food consumed by the fish and DW is the total weight gained $(\mathrm{g})$.

\section{Proximate composition}

Moisture was determined by drying the samples in an oven (Heraeus, D-63450, Hanau, Germany) at $105{ }^{\circ} \mathrm{C}$ to a constant weight (AOAC, 2005); lipids were extracted according to Kinsella et al. (1977) and expressed as mg/100 $\mathrm{g}$ of wet muscle; crude ash was determined by incineration in a muffle furnace (Isuzu, Tokyo, Japan) at $600^{\circ} \mathrm{C}$ for $3 \mathrm{~h}$ (AOAC 2005); crude protein was determined by the Kjeldahl method $(\mathrm{N} \times$ 6.25) using an automatic Kjeldahl system (230-Hjeltec Analyzer, Foss Tecator, Höganäs, Sweden) (AOAC, 2005).

\section{Statistical analysis}

Data were analyzed by two-way analysis of variance $(3 \times 3)(G L M)$ followed by Duncan's multiple range test. All data are expressed as mean \pm SD. The significance of results was at $5 \%$.

\section{RESULTS AND DISCUSSION}

Results of growth performance (weight gain, specific growth rate and feed conversion ratio) of the juvenile bream fed the diet containing different levels of lysine and methionine are shown in Table 1. In several studies the important role of lysine and methionine on growth performance of fish species has been shown. Juvenile grass carp Ctenopharyngodon idella (Wang et al., 2005), cobia Rachycentron canadum (Zhou et al., 2007), Pacific threadfin Polydactylus sexfilis (Deng et al., 2010), large yellow croaker Pseudosciaena crocea (Zhang et al., 2008), turbot Scophthalmus maximus (Peres and Oliva-Teles, 2008) and gibel carp Carassius auratus gibelio (Hu et al., 2008) had higher specific growth rate when fed the diet contained lysine.

In the present study bream juveniles fed the control diet showed slightly lower SGR $(0.36 \%)$ compared to other fish that received supplemented amino acids diet. Juvenile bream fed the diet containing both lysine and methionine (treatment codes 4, 6, 8 and 9) had slightly higher SGR (0.44-0.69\%) when compared to those fed the diet supplemented with only lysine or methionine (0.28-0.43\%). However a slightly higher specific growth rate was observed in bream juveniles fed the diet contained lysine and methionine at $0.6 \%$ (treatment code 9). When fish meal was partially replaced by poultry by-product meal and bone and meat meal in gible carp commercial diet, lysine and methionine were effective in maintaining the growth performance of the fish (Hu et al., 2008). Feed conversion ratio (FCR) was significantly affected by the dietary treatment, however fish fed diet contained lysine and methionine at $0.6 \%$ had slightly lower FCR when compared to the fish received control or supplemented diet

Table 1 - Initial body weight, final body weight, specific growth rate and feed conversion ratio of bream juvenile fed the experimental diets*

\begin{tabular}{ccccccc}
\hline \hline $\begin{array}{c}\text { Diet } \\
\text { code }\end{array}$ & $\begin{array}{c}\text { Lysine } \\
(\%)\end{array}$ & $\begin{array}{c}\text { Methionine } \\
(\%)\end{array}$ & $\begin{array}{c}\text { Initial } \\
\text { weight }(\mathrm{g})\end{array}$ & $\begin{array}{c}\text { Final } \\
\text { weight }(\mathrm{g})\end{array}$ & $\begin{array}{c}\text { Specific growth } \\
\text { rate }(\%)\end{array}$ & $\begin{array}{c}\text { Feed conversion } \\
\text { ratio }\end{array}$ \\
\hline 1 & 0 & 0 & 0.82 & $0.92^{\mathrm{abc}}$ & 0.36 & $7.43^{\mathrm{ab}}$ \\
2 & 0.3 & 0 & 0.73 & $0.79^{\mathrm{c}}$ & 0.28 & $10.88^{\mathrm{a}}$ \\
3 & 0.6 & 0 & 0.84 & $0.95^{\mathrm{ab}}$ & 0.43 & $9.84^{\mathrm{a}}$ \\
4 & 0 & 0.3 & 0.96 & $1.04^{\mathrm{a}}$ & 0.29 & $10.02^{\mathrm{a}}$ \\
5 & 0.3 & 0.3 & 0.74 & $0.89^{\mathrm{bc}}$ & 0.64 & $8.55^{\mathrm{ab}}$ \\
6 & 0.6 & 0.3 & 0.76 & $0.92^{\mathrm{abc}}$ & 0.61 & $4.99^{\mathrm{b}}$ \\
7 & 0 & 0.6 & 0.82 & $0.91^{\mathrm{abc}}$ & 0.37 & $7.94^{\mathrm{bb}}$ \\
8 & 0.3 & 0.6 & 0.86 & $0.98^{\mathrm{ab}}$ & 0.44 & $10.23^{\mathrm{a}}$ \\
9 & 0.6 & 0.6 & 0.74 & $0.89^{\mathrm{bc}}$ & 0.69 & $6.72^{\mathrm{ab}}$ \\
\hline \hline
\end{tabular}

”Mean values with the same letter for each column are not significantly different $(P>0.05)$ 
Table 2 - Proximate composition (\%) of whole body of bream juvenile fed the experimental diets.

\begin{tabular}{ccccccc}
\hline \hline Diet code & Lysine (\%) & Methionine (\%) & Protein & Lipid & Ash & Moisture \\
\hline 1 & 0 & 0 & $14.06^{\mathrm{ab}}$ & 3.42 & 2.46 & $77.96^{\mathrm{b}}$ \\
2 & 0.3 & 0 & $14.76^{\mathrm{a}}$ & 2.89 & 3.60 & $78.33^{\mathrm{ab}}$ \\
3 & 0.6 & 0 & $13.74^{\mathrm{ab}}$ & 2.14 & 3.20 & $78.26^{\mathrm{ab}}$ \\
4 & 0 & 0.3 & $12.87^{\mathrm{ab}}$ & 1.10 & 2.77 & $79.35^{\mathrm{ab}}$ \\
5 & 0.3 & 0.3 & $13.47^{\mathrm{ab}}$ & 1.05 & 3.30 & $79.00^{\mathrm{ab}}$ \\
6 & 0.6 & 0.3 & $13.61^{\mathrm{ab}}$ & 1.52 & 3.62 & $78.80^{\mathrm{ab}}$ \\
7 & 0 & 0.6 & $13.39^{\mathrm{ab}}$ & 0.76 & 3.37 & $78.23^{\mathrm{ab}}$ \\
8 & 0.3 & 0.6 & $14.00^{\mathrm{ab}}$ & 1.11 & 2.92 & $78.93^{\mathrm{ab}}$ \\
9 & 0.6 & 0.6 & $12.19^{\mathrm{b}}$ & 1.64 & 2.92 & $80.36^{\mathrm{a}}$ \\
\hline \hline
\end{tabular}

${ }^{*}$ Mean values with the same letter for each column are not significantly different $(P>0.05)$

(in the range of 7.43-10.88) except the juvenile fed diet supplemented with $0.6 \%$ lysine and $0.3 \%$ methionine which had the lowest FCR (4.99, Table 1).

The proximate compositions of whole body of bream juveniles fed the diet containing lysine and methionine are shown in Table 2 . Whole body protein content in juveniles fed the diet code $1,3,4,5,6,7$ and 8 were not significantly different $(12.87-14.00 \%)$. Maximum body protein content $(14.76 \%)$ was observed in juveniles received diet supplemented with $0.3 \%$ lysine (diet code 2 ). Most of the juveniles had similar moisture content irrespective of the treatment except for the fish fed the diet code 1 and 9. Dietary treatments did not affect body ash and lipid content in bream juveniles. Similarly in juvenile Pacific threadfin (Polydactylus sexfilis) dietary lysine did not affect body ash content (Deng et al., 2010). Moisture, lipid and ash content in whole body of juvenile cobia were not significantly affected by the dietary lysine (Zhou et al., 2007). In gibel carp fed diet supplemented with lysine and methionine, carcass composition did not affected by dietary treatment (Hu et al., 2008).

In conclusion, the results of the present study showed that supplementation of diet with both lysine and methionine can better improve the growth performance of the fish and maximum specific growth rate was obtained when fish fed diet contained both lysine and methionine at $0.6 \%$

\section{REFERENCES}

Amini, F., Zamini, A.A., Ahmadi, M.R. 2007. Intergeneric Hybridization between Kutum, Rutilus frisii kutum, and Bream, Abramis brama orientalis, of the Caspian Sea. J. World Aqua. Soc. 38: 497-505.

AOAC, 2005. Official methods of analysis, 18th edn, Association of Official Analytical Chemists, Gaithersburg.

Deng, D-F., Dominy, W., Ju, Z.Y., Koshio, S., Murashige, R., Wilson, R.P., 2010. Dietary lysine requirement of juvenile Pacific threadfin (Polydactylus sexfilis). Aquaculture, 308: 44-48.

Ghasemi, A., Keyvanshokooh, S., ShahriariMoghadam, M., Khara, H., Sourinejad, I., 2007. Genetic comparison of Iranian and Azeri populations of the oriental bream Abramis brama orientalis (Berg) using microsatellites. Aqua. Res. 38: 1742-1746.

Ghomi, M.R., Shahriari, R., Faghani Langroudi, H., Nikoo, M., 2012. The effects of dietary enzyme on some blood biochemical parameters of the cultured great sturgeon Huso huso juveniles. Comp. Clin. Pathol. 21(2): 201-204.

Hu, M., Wang, Y., Wang, Q., Zhao, M., Xiong, B., Qian, X., Zhao, Y., Luo, Z., 2008. Replacement of fish meal by rendered animal protein ingredients with lysine and methionine supplementation to practical diets for gibel carp, Carassius auratus gibelio. Aquaculture 275: 260-265.

Kiabi, B.H., Abdoli, A., Naderi, M., 1999. Status of the fish fauna in the south Caspian basin of Iran. Zool. Mid. East 18: 57-65.

Mai, K., Lu, Z., Ai, Q., Duan, Q., Zhang, C., Li, H., Wan, J., Liufu, Z., 2006. Dietary lysine requirement of juvenile Japanese seabass, Lateolabrax japonicus. Aquaculture 258: 535-542.

Peres, H., Oliva-Teles, A., 2008. Lysine requirement and efficiency of lysine utilization in turbot (Scophthalmus maximus) juveniles. Aquaculture 275: 283-290.

Schwarz, F.J., Kirchgessner, M., Deuringer, U., 1998. Studies on the methionine requirement of carp (Cyprinus carpio L.). Aquaculture 161: 121-129.

Singh, P., Maqsood, S., Samoon, M.H., Phulia, V., Danish, M., Singh Chalal, R., 2011. Exogenous supplementation of papain as growth promoter in diet of fingerlings of Cyprinus carpio. Int. Aquat. Res. 3: 1-9.

Wang, S., Liu, Y-J., Tian, L-X., Xie, M-Q., Yang, H-J., Wang, Y., Liang, G-Y., 2005. Quantitative dietary lysine requirement of juvenile grass carp 
Ctenopharyngodon idella. Aquaculture 249: 419-429.

Zhang, C., Ai, Q., Mai, K., Tan, B., Li, H., Zhang, L., 2008. Dietary lysine requirement of large yellow croaker, Pseudosciaena crocea R. Aquaculture 283: 123-127.

Zhou, Q-C., Wu, Z-H., Tan, B-P., Chi, S-Y., Yang, Q-H., 2006. Optimal dietary methionine requirement for Juvenile Cobia (Rachycentron canadum). Aquaculture 258: 551-557.
Zhou, Q-C., Wu, Z-H., Chi, S-Y., Yang, Q-H., 2007. Dietary lysine requirement of juvenile cobia (Rachycentron canadum). Aquaculture 273: 634-640.
Submetido: Novembro/2011 Revisado: Março/2012 Aceito: Agosto/2012 